DRUG AND CHEMICAL TOXICOLOGY

Vol. 27, No. 3, pp. 257-268, 2004

\title{
Genotoxicity of Aspartame
}

\author{
Eyyüp Rencüzoğulları, ${ }^{1 * *}$ Berrin Ayaz Tüylü, ${ }^{3}$ Mehmet Topaktaş, ${ }^{1}$ \\ Hasan Basri İla, ${ }^{1}$ Ahmet Kayraldız, ${ }^{2}$ Mehmet Arslan, ${ }^{2}$ \\ and Songül Budak Diler ${ }^{2}$ \\ ${ }^{1}$ Biology Department, Faculty of Arts and Sciences and ${ }^{2}$ Biology Department, \\ Natural and Applied Sciences Institute, Çukurova University, Adana, Turkey \\ ${ }^{3}$ Biology Department, Faculty of Sciences, Anadolu University, \\ Eskişehir, Turkey
}

\begin{abstract}
In the present study, the genotoxic effects of the low-calorie sweetener aspartame (ASP), which is a dipeptide derivative, was investigated using chromosome aberration (CA) test, sister chromatid exchange (SCE) test, micronucleus test in human lymphocytes and also Ames/Salmonella/ microsome test. ASP induced CAs at all concentrations $(500,1000$ and $2000 \mu \mathrm{g} / \mathrm{ml})$ and treatment periods $(24$ and $48 \mathrm{~h})$ dosedependently, while it did not induce SCEs. On the other hand, ASP decreased the replication index (RI) only at the highest concentration for $48 \mathrm{~h}$ treatment period. However, ASP decreased the mitotic index (MI) at all concentrations and treatment periods dose-dependently. In addition, ASP induced micronuclei at the highest
\end{abstract}

*Correspondence: Dr. Eyyüp Rencüzoğulları, Biology Department, Faculty of Arts and Sciences, Çukurova University, 01330 Adana, Turkey; Fax: +90-3223386070; E-mail: reyyup@mail.cu. edu.tr. 


\begin{abstract}
concentrations only. This induction was also dose-dependent for 48 hours treatment period. ASP was not mutagenic for Salmonella typhimurium TA98 and TA100 strains in the absence and presence of S9 mix.

Key Words: Sweeteners; Aspartame; Chromosome aberrations; Sister chromatid exchange; Micronuclei; Ames test.
\end{abstract}

\title{
INTRODUCTION
}

Many non-nutritive sweeteners have been used in foods and beverages to allow people to enjoy the sweet taste without consuming sugar-associated calories, and therefore inducing weight gain. One of these sweeteners is aspartame. Aspartame $(\alpha-\mathrm{L}-$ aspartyl-L-phenylalanine 1-methylester) is a dipeptide artificial sweetener that is widely used as a non-nutritive sweetener in foods and drinks. ASP was discovered in 1965. In 1981, ASP became the first low calorie sweetener approved by the Food and Drug Administration (FDA) in more than 26 years.

ASP is used as a sweetener in food products including dry beverage mixes, chewable multi-vitamins, breakfast cereals, chewing gum, puddings and fillings, carbonated beverages, refrigerated and non-refrigerated ready to drink beverages, yogurt-type products and pharmaceuticals. The ministry of Agricultural (of Turkey) suggested that ASP may be used at a maximum dose of $5500 \mathrm{mg} / \mathrm{kg}$ (The ministry of Agricultural of Turkey, 1997). Butchko et al. (2002) reviewed a study on safety of ASP and reported that ASP is safe. It was reported that ASP did not induce DNA damage in rat hepatocytes (Jeffrey and Williams, 2000) and was not clastogenic in mice when given orally (Durnev et al., 1995). In addition, Molinary (1984) reported that ASP was not mutagenic in Ames Test and had no genotoxic effect in dominant-lethal and host mediated assay.

However, Shephard et al. (1991) reported that ASP has a weak mutagenic effect in Salmonella typhimurium TA100 and TA98 strains after nitrosation. As shown, some of the sweeteners have mutagenic effects and some of them such as saccharin caused cancer. Olney et al. (1996) reported that ASP may be carcinogenic in SpragueDawley rats. However, Ishii (1981) reported that ASP does not cause brain cancer in rats.

As shown, there are several studies suggesting that ASP has genotoxic effects but there are also several studies suggesting that ASP has no genotoxicity. At present, there is no published data on the induction of CA, SCE and micronuclei by ASP in human lymphocytes or mutagenic effects in S. typhimurium without nitrosation. These studies have been completed and are presented here.

\section{MATERIALS AND METHODS}

The test substance Aspartame phenylalanine methyl ester was obtained from Sigma (Cat. no: A5139, CAS no: 22839-47-0, FW: 294, 3). Purity of ASP is 99.9\%. The osmolality of ASP was measured using Roebling automatic osmometer. The $\mathrm{pH}$ of the 


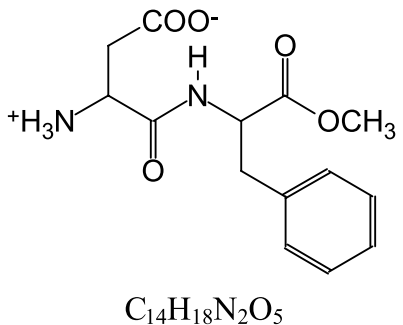

Figure 1. N-L- $\alpha$-aspartyl-L-phenylalanine 1-methylester.

medium was measured using WTW 315i (Germany) pH meter. The chemical structure and formula of ASP is shown in Fig. 1.

\section{CA and SCE Assay}

Whole blood $(0.2 \mathrm{ml})$ from four healthy donors (two male, two female, nonsmokers, age: 18-19) was added to $2.5 \mathrm{ml}$ chromosome medium B (Seromed, Biochrom cat. no.: F5023) supplemented with $10 \mu \mathrm{g} / \mathrm{ml}$ bromodeoxyuridine (Sigma cat. no.: B5002). The cultures were incubated at $37^{\circ} \mathrm{C}$ for $72 \mathrm{~h}$. The cells were treated with 500,1000 and $2000 \mu \mathrm{g} / \mathrm{ml}$ concentrations of ASP for $24 \mathrm{~h}$ (ASP was added $48 \mathrm{~h}$ after initiating the culture) and $48 \mathrm{~h}$ (ASP was added $24 \mathrm{~h}$ after initiating the culture). These concentrations were selected according to cytotoxicity of ASP. A negative control (untreated cultures) and a positive control (mitomycin-C, $0.3 \mu \mathrm{g} / \mathrm{ml}$, Kyowa, Hakko, Japan) were used. The test substance, ASP, and positive control mitomycin-C (MMC) were dissolved in bidistilled water. Colchicine $(0.06 \mu \mathrm{g} / \mathrm{ml}$, Sigma cat. no.: C9754) was present for the last $2 \mathrm{~h}$ of culture. To collect the cells, the cultures were centrifuged $(1200 \mathrm{rpm}, 15 \mathrm{~min})$, treated with hypotonic solution $(0.4 \% \mathrm{KCl})$ for $20 \mathrm{~min}$ at $37^{\circ} \mathrm{C}$, and then fixed in cold methanol:glacial acetic acid (3:1) for $20 \mathrm{~min}$ at room temperature. The treatment with fixative was repeated three times. Then the cells were spread on glass slides and air dried. The slides were stained with Giemsa according to fluorescence plus Giemsa technique (Speit and Haupter, 1985). 100 well spread metaphases per donor (a total of 400 metaphases per concentration) were examined at $1000 \times$ magnification for occurrence of different types of CA. The number of abnormal cells per concentration and treatment period were determined and the mean frequency of abnormal cells was calculated. The number of CA per cell (CA/cell) was calculated as well. For the occurrence of SCEs, a total 100 cells (25 cells from each donor) under second metaphases were examined. The metaphases were examined at $1000 \times$ magnification. The results were used to determine the mean number of SCE (SCE/ cell). In addition, a total 400 cells (100 cells from each donor) were scored for the determination of the replication index (RI). The MI was also determined by scoring 3000 cells from each donor. The MI explained the effects of the chemicals on G2 stage of cell cycle, and the RI reflects the effects of chemicals on S and G2 stages of the cycles. The RI was calculated according to the formula as follows: $\mathrm{RI}=(\mathrm{M} 1 \times 1)+$ $(\mathrm{M} 2 \times 2)+(\mathrm{M} 3 \times 3) /$ total scored cells. M1, M2 and M3 are the fraction of cells undergoing the first, second and third mitosis during 72 hours cells culture times. 


\section{Micronucleus Assay}

The micronucleus test was performed as described by Rothfus et al. (2000). The peripheral blood from 4 healthy donors was added to $2.5 \mathrm{ml}$ chromosome medium B and incubated at $37^{\circ} \mathrm{C}$ for $68 \mathrm{~h}$. The cells were treated with 500, 1000 and $2000 \mu \mathrm{g} / \mathrm{ml}$ concentrations of ASP for 24 and 48 hours as mentioned above. A negative and a positive control $(0.3 \mu \mathrm{g} / \mathrm{ml}$ Mitomycin-C) was also used. Cytochalasin B was added to cultures at a final concentrations of $6 \mu \mathrm{g} / \mathrm{ml} 44$ hours after initiating of the cultures. Cultures were harvested 24 hours later. Then, the cells were treated with hypotonic solution $(0.4 \% \mathrm{KCl})$, fixed once with fixative (methanol:glacial acetic acid, 5:1) mixed with an equal amount of $0.9 \% \mathrm{NaCl}$ for $20 \mathrm{~min}$, and then fixed twice with methanol/ glacial acetic acid $(5: 1)$ for $20 \mathrm{~min}$. The slides were air-dried and stained with 5\% Giemsa. The micronucleus frequency was determined by analysing 2000 binucleated cells for each donor from blinded slides. In addition, the ratio of binucleated to mononucleated cells was also scored by analysing 2000 cells for each donor.

\section{Salmonella/Microsome Test}

\section{Bacterial Strains}

Histidine deficient (his ${ }^{-}$) tester strains TA98 and TA100 of Salmonella typhimurium were kindly provided by L. K. Nakamura (Microbiologist Emeritus, Microbial Properties Research, United States Department of Agriculture, 1815 North University Street, Peoria, Illinois, 61604 USA). The TA98 strain is used for the detection of frameshift mutagens and TA100 strain for the detection of base pair substitution mutagens. Prior to use in the assay, each strain was checked for the presence of strain-specific marker as described by Maron and Ames (1983).

Mutagenicity Assay

The standard plate-incorporation assay was examined with Salmonella typhimurium TA98 and TA100 strains in the presence and absence of S9 mix according to Maron and Ames (1983). $0.5 \mathrm{ml}$ of S9 mix containing $50 \mu \mathrm{l}$ of $\mathrm{S} 9$ factor per plate was used for the assay. For the test, ASP was dissolved in distilled water and 50, 100, 250, 500, 1000 and $2000 \mu \mathrm{g}$ per plate were used. On the other hand, 4-NPD (4-nitrophenylene diamine) was used as a positive mutagen ( $200 \mu \mathrm{g} / \mathrm{plate})$ for TA98 and TA100. In the presence of S9 mix, 2-AF (2-aminoflourene) was used as positive mutagen $(20 \mu \mathrm{g} /$ plate) for both TA98 and TA100 strains. Each sample was evaluated with three replicate plates and all experiments were performed twice.

Preparation of S9

The male albino rats (Rattus norvegicus var. albinos) weighing 200 gr were pretreated with $80 \mathrm{mg} / \mathrm{kg}$ concentration of 3-methylcholanthrene (Oekanal, Cat. no: 45794) (dissolved in sunflower seed oil) for 5 days and the S9 fraction and S9 mix were prepared following the procedure of Maron and Ames (1983). The S9 tablets were purchased from Roche (Cat. no: 1.745.425). The freshly prepared S9 fraction is 


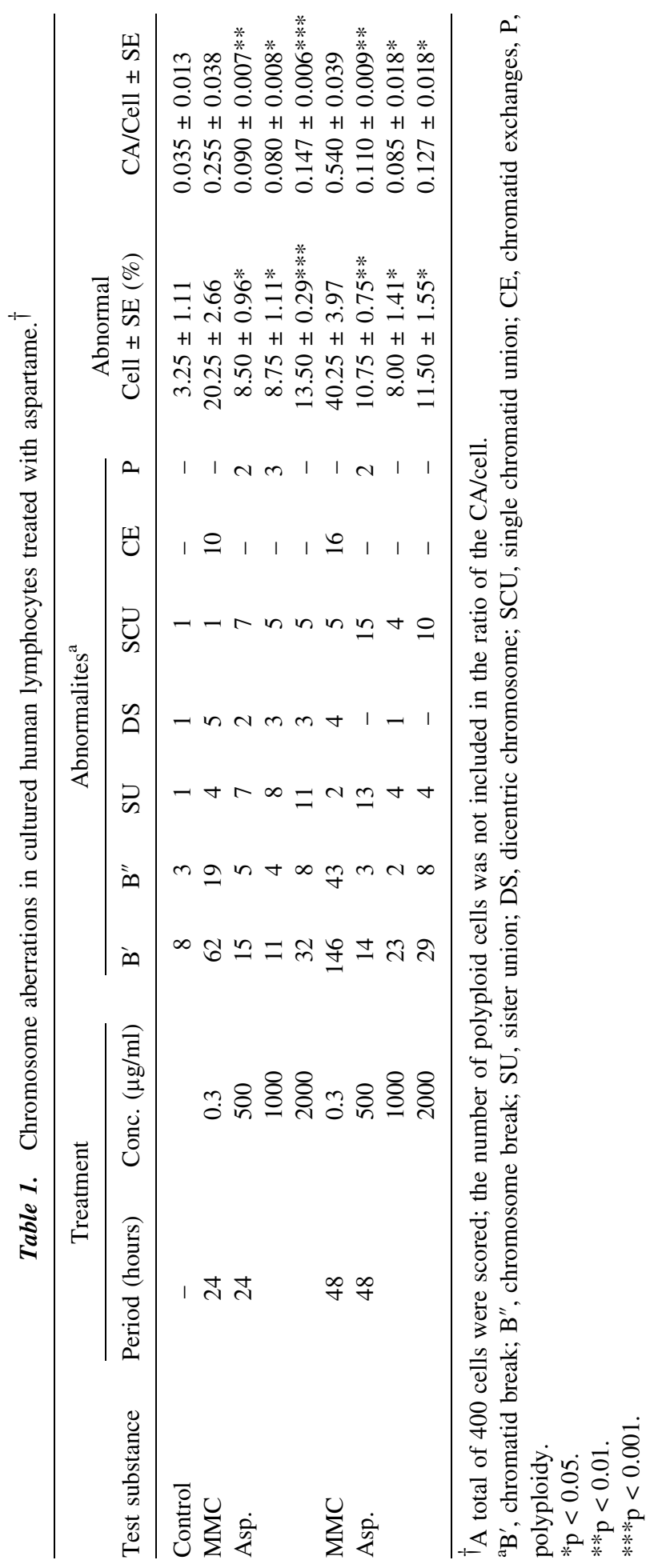




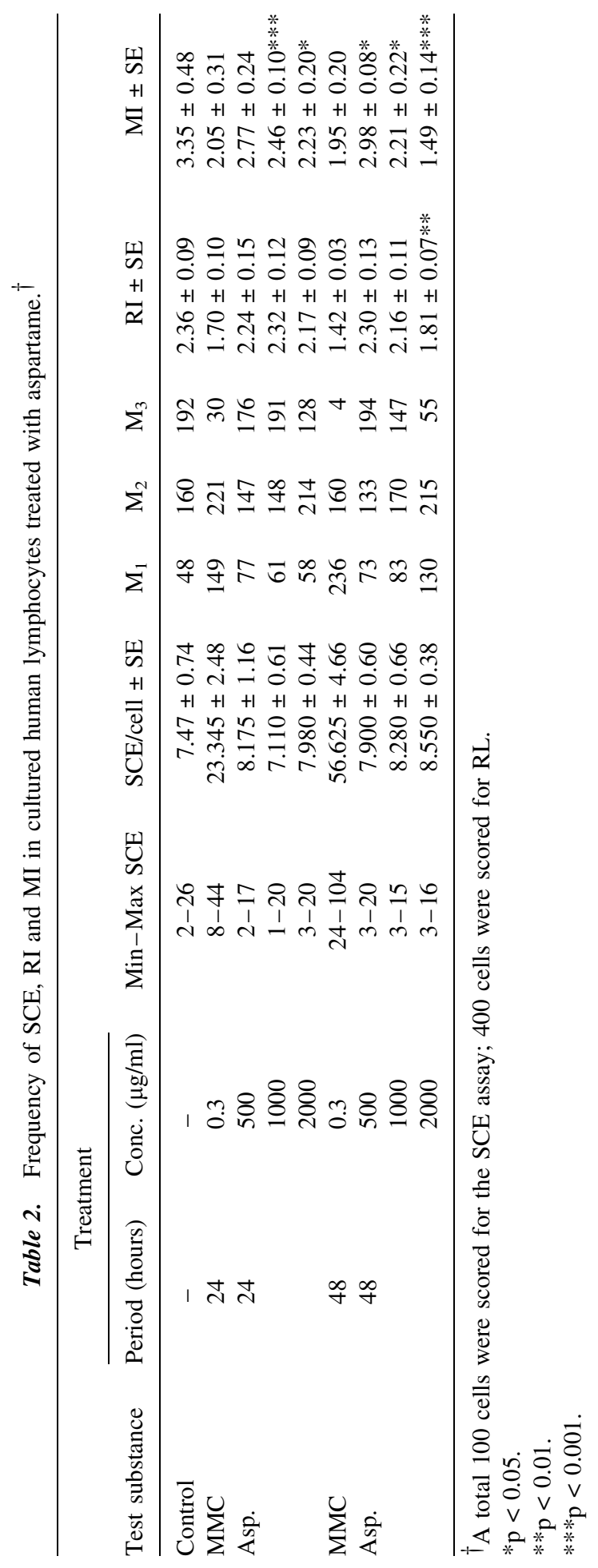


distributed in 1-ml portions in small plastic tubes frozen immediately and stored at $-35^{\circ} \mathrm{C}$. The $\mathrm{S} 9$ mix was prepared fresh for each mutagenicity assay. Each tablet was dissolved in $18 \mathrm{ml}$ bidistilled water supplemented with $2 \mathrm{ml}$ of $\mathrm{S} 9$ fraction.

\section{Statistical Significance}

Chromosome and chromatid gaps were not evaluated as CA (Mace et al., 1978). The significance between the percentage of abnormal cell, CA/cell, mean SCE, percentage of the micronucleated cells, RI and MI in treated cultures and their controls were determined using the t-test. Dose response relationships were determined from the correlation and regression coefficients and the corresponding regression lines for the percentage of abnormal cell, CA/cell, mean SCE, percentage of micronuclei, RI and MI.

The significance between control revertants and revertants of treated groups were also determined using t-test. Dose-response relationships were also determined using regression and correlation (r) test systems.

\section{RESULT}

ASP induced a significant increase of CAs at all concentrations and treatment periods compared to control (Table 1). However this increase was not dose-dependent. The potency of ASP on induction of CAs was lower than that caused by the positive control MMC. However, ASP did not induce the SCE (Table 2).

Chromatid breaks, chromosome breaks, sister union (union of sister chromatids of a chromosome) and single chromatid union (union of one chromatid of different chromosomes) were the most common chromosomal abnormalities.

Table 3. The frequency of micronuclei in cultured human lymphocytes treated with aspartame. ${ }^{\dagger}$

\begin{tabular}{|c|c|c|c|c|}
\hline \multirow[b]{2}{*}{ Test subst. } & \multicolumn{2}{|c|}{ Treatment } & \multirow{2}{*}{$\begin{array}{c}\text { Percent } \\
\text { micronucleated } \\
\text { binucleated cells }\end{array}$} & \multirow{2}{*}{$\begin{array}{c}\text { Binucleated } \\
\text { cells/mononucleated } \\
\text { cells }\end{array}$} \\
\hline & Periods (hours) & Concentr. $(\mu \mathrm{g} / \mathrm{ml})$ & & \\
\hline Control & - & - & $0.270 \pm 0.04$ & $0.130 \pm 0.01$ \\
\hline $\mathrm{MMC}^{\mathrm{a}}$ & 24 & $0.3 \mu \mathrm{g} / \mathrm{ml}$ & $1.130 \pm 0.14$ & $0.061 \pm 0.00$ \\
\hline \multirow[t]{3}{*}{ ASP } & 24 & 500 & $0.373 \pm 0.14$ & $0.096 \pm 0.01$ \\
\hline & & 1000 & $0.335 \pm 0.07$ & $0.072 \pm 0.00 *$ \\
\hline & & 2000 & $0.597 \pm 0.12 *$ & $0.069 \pm 0.00 *$ \\
\hline $\mathrm{MMC}^{\mathrm{a}}$ & 48 & $0.3 \mu \mathrm{g} / \mathrm{ml}$ & $5.697 \pm 0.35$ & $0.069 \pm 0.00$ \\
\hline \multirow[t]{3}{*}{ ASP } & 48 & 500 & $0.298 \pm 0.06$ & $0.062 \pm 0.00 *$ \\
\hline & & 1000 & $0.322 \pm 0.04$ & $0.058 \pm 0.00 *$ \\
\hline & & 2000 & $0.522 \pm 0.08^{*}$ & $0.040 \pm 0.00 *$ \\
\hline
\end{tabular}

${ }^{\dagger}$ A total of 8000 binucleated cells were scored.

${ }^{a}$ Only 7000 cells were scored due to excessive toxicity.

$* \mathrm{p}<0.05$. 


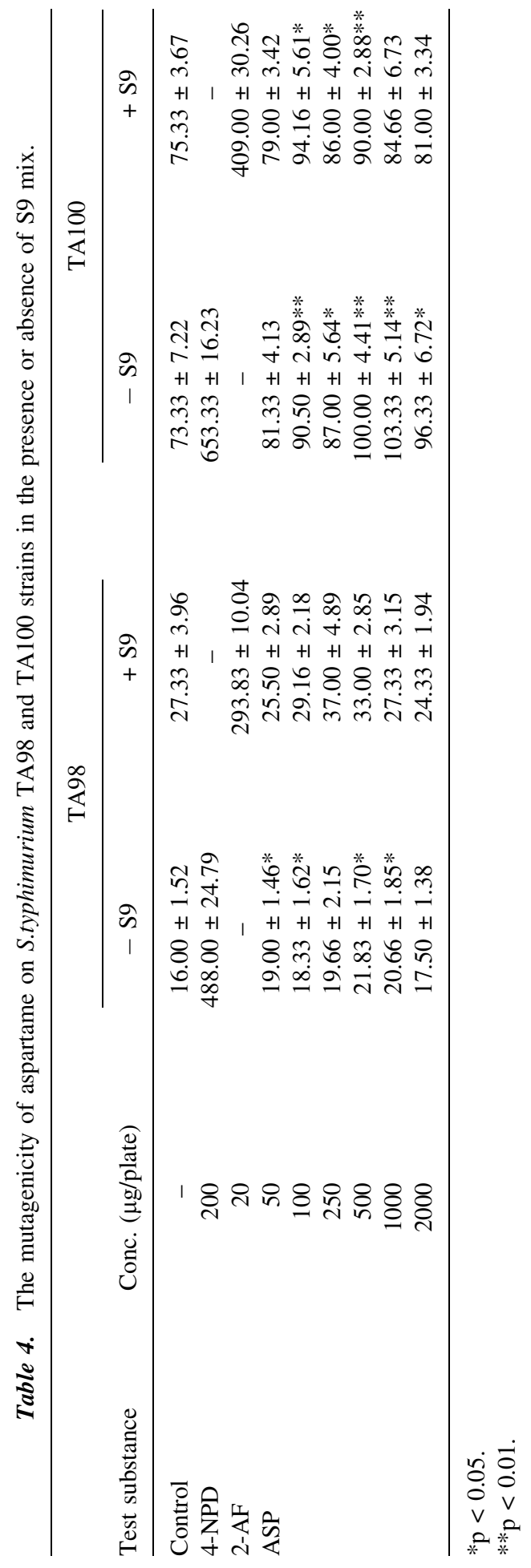


ASP did not decrease the RI except the highest concentration for $48 \mathrm{~h}$ treatment period. However, ASP significantly decreased the MI at all concentrations for 24 and $48 \mathrm{~h}$ treatment periods when compared with control (Table 2). This decrease was dosedependent ( $\mathrm{r}=-0.96$ and $\mathrm{r}=-0.97$, respectively).

ASP induced micronucleus formation at $2000 \mu \mathrm{g} / \mathrm{ml}$ concentrations for 24 and 48 $\mathrm{h}$ treatment periods (Table 3). This effect was also dose-dependent for 48 hours treatment period $(\mathrm{r}=0.97)$. ASP also dose-dependently decreased the ratio of binucleated to mononucleated cells for 24- and 48-hour treatment periods $(\mathrm{r}=-0.81$ and $\mathrm{r}=-0.98$, respectively) (Table 3 ). This decrease was clearly related with the decrease in $\mathrm{MI}$ in Table 2.

ASP did not change the $\mathrm{pH}$ and the osmolality of the medium. The osmolality was measured as 342 milliosmol in control and 346 milliosmomol in the maximum dose of ASP $(2000 \mu \mathrm{g} / \mathrm{ml})$.

ASP did not increase the number of revertants of TA98 in the absence or presence of S9 mix. ASP slightly increased the number of revertants of TA100 in the absence of S9 mix but this is not considered to represent a positive response. There is no dosedependent effect (Table 4). The effect of ASP on TA100 strain was greater than TA98 strain.

\section{DISCUSSION}

In this study, ASP significantly induced CA and micronucleus formation and showed a cytotoxic effect by decreasing the MI. However, ASP did not induce the SCE and it had no mutagenic effect on the tester strains TA98 and TA100 of S. typhimurium in the presence and absence of S9 mix.

ASP is hydrolysed in the gut to yield aspartic acid, phenylalanine, methanol and cyclised diketopiperazine (Maher, 1987; Ranney and Oppermann, 1979). There are a lot of studies on genotoxicity of metabolities of ASP (Austin et al., 1992; Brook and Chandley, 1985; Generoso et al., 1995; Sargentini and Smith, 1986).

Shephard et al. (1991) reported that ASP has a weak mutagenic effect in Ames test after nitrosation. Shephard et al. (1993) reported that, in the human stomach, the chain nitrosation of the amino acids (Phe) and aspartame might be more important than the reactions at the primary amino group. However, Butchko et al. (2002) reported that ASP is safe and it was also reported that ASP was not mutagenic and clastogenic in animals (Durnev et al., 1995; Jeffrey and Williams, 2000; Molinary, 1984). In the present study, it was found that ASP had a genotoxic effect using CA and micronuclei test in human lymphocytes but had no mutagenic effect using Ames/Salmonella/microsome test and did not induce SCE, in human lymphocytes.

It has been reported that ASP does not cause brain and bladder tumours (Hagiwara et al., 1984; Ishii, 1981; Ito et al., 1984) however, there are some reports that ASP (Olney et al., 1996) and especially its metabolites, phenylalanine and methanol (Schwartz, 1999) increased the breast, brain and prostate cancer incidence. The data obtained from a study carried out by FDA supported the report of Olney et al., 1996 in the assay on 320 Sprague-Dawley rats fed with ASP which caused brain cancer [According to Study E33-34 in master file 134 on ASP from Weihrauch et al. (2001)]. 
Schwartz (1999) also reported that methanol is converted to formaldehyde which then accumulates in the cells. Formaldehyde has been considered an inducer of cancer and acts to alter DNA (Ewertz, 1993; Ewertz and Gill, 1990). Olney et al. (1996) reviewed and explained that ASP had mutagenic potential. Ahmed and Thomas (1992) reported that cyclamate (sweetener) was not carcinogenic by itself; however, it might have cancer-promoting or carcinogenic activities. In this study, we found that ASP did appear to have genotoxic potential consistent with potential carcinogenicity.

According to these results, phenyalanine and methanol, which are metabolic products of ASP, have a genotoxic risk for humans. In contrast, ASP was not found as a mutagen in in vivo studies. However, in the present study, ASP induced CA and micronuclei in human lyphocytes dose-dependently.

ASP did not change the osmolality of the medium at the maximum concentrations (346 milliosmol) when compared with untreated medium (342 milliosmol). It was reported that a deviation from physiological osmolality (approximately 300 milliosmol) can lead to genotoxic effects (Nowak, 1984, 1997; Seeberg et al., 1989). According to these results, we can conclude that ASP induced CA and percentage of micronuclei by itself because it did not alter the $\mathrm{pH}$ and osmolality of the medium.

As shown, there are several contradictory studies about genotoxicity and carcinogenicity of ASP. However, it must be taken into account that ASP induced the $\mathrm{CA}$ and micronuclei formation in a dose-dependent manner. It is not possible to conclude that ASP is safe according to these results. Therefore, it is necessary to be careful when using it in food and beverages as a sweetener.

\section{ACKNOWLEDGMENTS}

This study was funded by Cukurova University Research Fund FEF 2002 BAP 21. We also thank Mr. L.K. Nakamura for his kind collaboration.

\section{REFERENCES}

Ahmed, F. E., Thomas, D. B. (1992). Assessment of the carcinogenicity of the nonnutritive sweetener cyclamate. Crit. Rev. Toxicol. 22(2):81-118.

Austin, M. J., Han, Y. H., Povirk, L. F. (1992). DNA sequence analysis of mutations induced by melphalan in the $\mathrm{CHO}$ aprt locus. Cancer Genet. Cytogenet. 64(1):6974.

Brook, J. D., Chandley, A. C. (1985). Testing of 3 chemical compounds for aneuploidy induction in the female mouse. Mutat. Res. 157(2-3):215-220.

Butchko, H. H., Stargel, W. W., Comer, C. P., Mayhew, D. A., Benninger, C., Blackburn, G. L., de Sonneville, L. M., Geha, R. S., Hertelendy, Z., Koestner, A., Leon, A. S., Liepa, G. U., McMartin, K. E., Mendenhall, C. L., Munro, I. C., Novotny, E. J., Renwick, A. G., Schiffman, S. S., Schomer, D. L., Shaywitz, B. A., Spiers, P. A., Tephly, T. R., Thomas, J. A., Trefz, F. K. (2002). Aspartame: review of safety. Regul. Toxicol. Pharmacol. 35(2):1-92.

Durnev, A. D., Oreshchenko, A. V., Kulakova, A. V., Beresten, N. F., Seredenin, S. B. 
(1995). Clastogenic activity of dietary sugar substitutes. Vopr. Med. Khim. 41(4):3133.

Ewertz, M. (1993). Breast cancer in Denmark. Incidence, risk factors, and characteristics of survival. Acta Oncol. 32:595-615.

Ewertz, M., Gill, C. (1990). Dietary factors and breast-cancer risk in Denmark. Int. J. Cancer 46:779-784.

Generoso, W. M., Witt, K. L., Cain, K. T., Hughes, L., Cacheiro, N. L., Lockhart, A. M., Shelby, M. D. (1995). Dominant lethal and heritable translocation test with chlorambucil and melphalan in male mice. Mutat. Res. 345(3-4):167-180.

Hagiwara, A., Fukushima, S., Kitaori, M., Shibata, M., Ito, M. (1984). Effects of three sweeteners on the rat urinary bladder carcinogenesis initiated by N-butyl-N-(4hydroxybuthyl)-nitrosamine. Gann 75(9):763-768.

Ishii, H. (1981). Incidence of brain tumors in rats fed aspartame. Toxicol. Lett. 7(6):433438.

Ito, N., Fukushima, S., Shirai, T., Hagiwara, A., Imaida, K. (1984). Drugs, food additives and natural products as promoters in rat urinary bladder carcinogenesis. IARC Sci. Publ. 56:399-407.

Jeffrey, A. M., Williams, G. M. (2000). Lack of DNA-damaging activity of five nonnutritive sweeteners in the rat hepatocyte/DNA repair assay. Food Chem. Toxicol. 38(4):335-338.

Mace, M. L. Jr., Daskal, Y., Wray, W. (1978). Scanning-electron microscopy of chromosome aberrations. Mutat. Res. 52:199-206.

Maher, T. J. (1987). Natural food constituents and food additives: the pharmacologic connection. J. Allergy Clin. Immunol. 79:413-422.

Maron, D. M., Ames, B. N. (1983). Revised method for the Salmonella mutagenicity test. Mutat. Res. 113:173-215.

Molinary, S. V. (1984). Preiclinical Studies of Aspartame in Non-primate Animals. In: Stegink, L. D., Tiler, L. S. Jr., eds. Aspartame, Physiology and Biochemistry. New York: Marcel Dekker, pp. 289-306.

Nowak, C. (1984). Induction of chromosomal aberrations by hypotonic culture conditions is dependent of the S-phase in V79 hamster cells. Environ. Mol. Mutagen. 13(1):44-49.

Nowak, C. (1997). Studies on the ability of hypotonic solutions to induce chromosomal aberrations in V79 cells. Teratog. Carcinog. Mutagen. 7(6):515-525.

Olney, J. W., Farber, N. B., Spitznagel, E., Robins, L. N. (1996). Increasing brain tumors rates: is there a link to aspartame? J. Neuropathol. Exp. Neurol. 55(11):11151123.

Ranney, R. E., Oppermann, J. A. (1979). A review of the metabolism of the aspartyl moiety of aspartame in experimental animals and man. J. Environ. Pathol. Toxicol. 2(4):979-985.

Rothfus, A., Schütz, P., Bochum, S., Volm, T., Eberhardt, E., Kreirenberg, R., Vogel, W., Speit, G. (2000). Induced micronucleus frequencies in peripheral lymphocytes as a screening test for carriers of a BRCA1 mutation in breast cancer families. Cancer Res. 60:390-394.

Sargentini, N. J., Smith, K. C. (1986). Mutagenesis by normal metabolites in Escherichia coli: phenylalanine mutagenesis is dependent on error-prone DNA repair. Mutat. Res. 161(2):113-118. 
Schwartz, G. R. (1999). Aspartame and breast and other cancers. West J. Med. 171:300301 .

Seeberg, A. H., Mosesso, P., Forster, R. (1989). High-dose-level effects in mutagenicity assays utilizing mammalian cells in culture. Mutagenesis 3(3):213-218.

Shephard, E. E., Meier, I., Lutz, W. K. (1991). Alkylating potency of nitrosated amino acids and peptides. IARC Sci. Publ., 105:383-387.

Shephard, S. E., Wakabayashi, K., Nagao, M. (1993). Mutagenic activity of peptides and the artificial sweetener aspartame after nitrosation. Food Chem. Toxicol. 31(5):323-329.

Speit, G., Haupter, S. (1985). On the mechanisms of differential giemsa staining of bromodeoxyuridine-substituted chromosomes. II Differences between the demonstration of sister chromatid differentiation and replication patterns. Hum. Genet. $70: 126-129$.

The ministry of Agricultural of Turkey. (1997). Food Codex. Globus World Publications, Turkey, pp. 46-47.

Weihrauch, M. R., Diehl, V., Bohlen, H. (2001). Künstliche Süßstoffe-Haben sie ein kanzerogenes potential? Med. Klin. 96:670-675. 
Copyright of Drug \& Chemical Toxicology is the property of Marcel Dekker Inc. and its content may not be copied or emailed to multiple sites or posted to a listserv without the copyright holder's express written permission. However, users may print, download, or email articles for individual use. 